näinen omaleimainen kielimuotonsa, siis kieli muiden itämerensuomalaisten kielten joukossa.

Vesa Koivisto

etunimi.sukunimi@uef.fi

\section{Lähteet}

Bubrih, D. V. - Beljakov, A. A. Punžına, A. V. 1997: Dialektologičeskij atlas karel'skogo jazyka. Karjalan kielen murrekartasto. Suomalais-Ugrilaisen Seuran Toimituksia 97. Helsinki: Suomalais-Ugrilainen Seura.

Posti, LAURi 1980: The origin and development of the reflexive conjugation in the Finnic languages. - Osmo Ikola (toim.), Congressus Quintus Internationalis Fenno-Ugristarum I s. 111-144. Turku.

\title{
Ensimmäinen englanninkielinen koltansaamen kielioppi
}

Timothy Feist: A grammar of Skolt Saami. Suomalais-Ugrilaisen Seuran Toimituksia 273. Helsinki: Suomalais-Ugrilainen Seura 2015. 414 s. ISBN 978-952-5667-74-5.

Koltansaame kuuluu itäsaamelaisiin kieliin. Sen lähimmät sukukielet ovat inarinsaame lännessä ja kiltinänsaame sekä akkalansaame idässä. Kieltä puhutaan nykyisin lähinnä Inarin kunnan alueella, mutta perinteisesti sitä on puhuttu myös Kuolan niemimaan länsiosissa ja Norjan Neidenissä. Puhuma-alueen muutos johtuu siitä, että Suomelle kuulunut Petsamo luovutettiin toisen maailmansodan jälkeen Neuvostoliitolle ja alueen kolttasaamelaiset uudelleenasutettiin Suomen puolelle. Koltansaamea pidetään vakavasti uhanalaisena; arviot puhujamäärästä vaihtelevat 150:n ja noin 300:n välillä. Suurin osa puhujista on keski-ikäisiä tai vanhuksia.

Ensimmäinen kuvaus Suonikylän (nyk. Sevettijärven) murteen pohjalle luodusta koltansaamen kirjakielestä on vuodelta 1973 teoksessa Koltansaamen opas (Korhonen, Mosnikoff \& Sammallahti 1973). Vuonna 2009 julkaistiin Koltansaamen koulukielioppi (Moshnikoff, Moshnikoff \& Koponen 2009), jossa pyrittiin esittämään kieliopin pääkohdat kouluopetusta silmällä pitäen. Nyt arvioitava Timothy Feistin teos A grammar of Skolt Saami on merkittävä lisäys aikaisempaan tutkimuskirjallisuuteen, sillä se on ensimmäinen englanninkielinen ja samalla laajin koltansaamen kieliopin kuvaus. Teos pohjautuu tekijän väitöskirjaan (Feist 2010).

\section{Lähtökohdat}

Feistin kielioppi perustuu ensisijaisesti kenttätöihin, joita hän teki kolttien parissa vuosina 2006-2009. Omien aineistojensa lisäksi tekijä on käyttänyt Kotimaisten kielten keskuksen eli Kotuksen nauhoitearkiston aineistoja, joita äidinkieliset kolttasaamelaiset olivat litteroineet, sekä Maaddârääjji mainnâz -satukirjaa (Mosnikoff 1992). Satukirjan tekstit on litteroitu ja toimitettu Kotuksen nauhoitearkiston äänitteistä, joista suurimman osan tallensi Mikko Korhonen 1960- ja 1970-luvuilla. Osa satukirjan teksteistä on liitetty kieliopin loppuun käännettyinä ja glossattuina (luku 11). Sivumäärällisesti nämä tekstit 
kattavat kieliopista kaikkiaan neljäsosan. Koska Feistin kielioppi on luonteeltaan deskriptiivinen, olisi ollut suotavaa, että tutkimusaineistona olisi käytetty alkuperäisiä arkistonauhoitteita eikä niiden pohjalta toimitettua kirjaa, jossa kieltä on viety normitetun yleiskielen suuntaan ja puhdistettu suomen kielen vaikutteista. Ylipäänsä Feistin teoksessa suomen kielestä lainatut rakenteet sekä koodinvaihto koltansaamen ja suomen välillä on jätetty lähes kokonaan mainitsematta, vaikka niitä esiintyy runsaasti hänen hyödyntämissään aineistoissa.

Fennougristiikan ulkopuolelta tulevana tutkijana Feistin näkökulma on hiukan erilainen kuin mihin saamelaiskielten tutkimuksessa ehkä on totuttu. Hän käsittelee koltansaamea omana itsenäisenä kielenään sen omilla ehdoilla eikä suurempien ja tunnetumpien sukukielten kautta, mitä voidaan pitää tämän kieliopin vahvuutena. Lähestymistapa on varsin tiukasti synkroninen. Tekijä pyrkii kuvaamaan kielen tämänhetkistä systeemiä ottamatta kantaa sen taustalla oleviin historiallisiin prosesseihin. Vertailua sukukielten ja kantakielten sanoihin tai muotoihin harrastetaan vain vähän (koko teoksessa kolme kertaa erinäisten äännekehityksen yksityiskohtien valaisemiseksi, ks. s. 84, 100 ja 147). Edellä mainitusta seuraa toisaalta myös hiukan kömpelöitä analyyseja, jotka olisi voinut selittää elegantimmin kielihistorian avulla. Esimerkiksi sopii yksikön illatiivissa omistustaivutuksen yhteydessä esiintyvän s:n selittäminen epenteettiseksi (s. 165), vaikka todellisuudessa se on jäänne historiallisesta latiivin päätteestä (vrt. suomen ulos, alas ym.)

Teos alkaa laajahkolla johdantoluvulla, jossa esitellään koltansaamen kieliyhteisö, puhuma-alue, sosiolingvistinen tilanne, geneettiset suhteet, aiempi tutkimus ja nykyinen ortografia. Lisäksi kerrotaan lyhyesti murrejaosta ja kolttasaamelaisten lähihistoriasta, erityisesti uudelleenasuttamisesta Sevettijärvelle ja Nellimiin. Feistin mukaan (s. 23) hänen teoksensa on kuvaus Paatsjoen ja Suonikylän (nyk. Nellimin ja Sevettijärven) murteista, jotka ovat Suomessa puhutun koltansaamen kaksi päämurretta. Tämä on paljon luvattu siihen nähden, että teoksessa ei ole käsitelty edes murteiden tavallisimpia eroja. Näihin kuuluvat esimerkiksi duaalin verbintaivutus, joka on säilynyt Paatsjoen murteessa mutta kadonnut Suonikylän murteesta, sekä jälkitavujen supistumavokaalin $u$ muuttuminen $\hat{a}$ :ksi Paatsjoen murteessa (esim. Suonikylä puõccu 'porot' vs. Paatsjoki puõccâ; Sammallahti 1998: 31). Feistin teosta voidaan siis pitää vain Sevettijärven murteen kuvauksena.

\section{Fonologiaa ja morfologiaa}

Toisessa luvussa käsitellään koltansaamen fonologiaa. Apuna on käytetty spektrogrammikuvia, jotka havainnollistavat hyvin eri äänteiden ominaisuuksia ja varsinkin suprasegmentaalisen palatalisaation vaikutusta äänneympäristöön. Luvussa pohditaan myös mahdollisen kymmenennen vokaalifoneemin $/ \varepsilon /$ olemassaoloa. Feist perustelee varsin vakuuttavasti, että kyseessä on foneemin /e/ allofoni. Luvun loppuun on listattu äänteenmuutoksia, jotka erottavat nuorten ja vanhojen puhujien kieltä. Eroina mainitaan esimerkiksi affrikaatan $\check{c}$ sibilantistuminen sekä lateraalin $l$ vokaaliutuminen palatalisoitumattomassa painotahdissa.

Toisen luvun alussa esitellään painotahdin rakenne, jonka kuvaus on otettu suoraan pohjoissaamen tutkimuksesta. Pohjoissaamen kuvauksessa tahdin maksimipituus on kolme tavua. Tämän kuvauksen soveltaminen mekaanisesti koltansaameen on ongelmallista. Vertailu pohjoissaamen kolmitavuisten tahtien (esim. máinnastit) ja koltansaamen vastaavien muotojen (esim. mainsted) välillä nimittäin osoittaa, että koltansaamessa niin sanottu lateraalivokaali eli toisen tavun vokaali katoaa näissä muodoissa taikka redusoituu ylilyhyeksi. Feist on valinnut kolmitavui- 
sen painotahdin havainnollistamiseen sananmuodon, joka lähemmällä tarkastelulla paljastuu kahdesta tahdista koostuvaksi: ǩiičče'ped 'katselette'. Jo vertailu pohjoissaamen vastaavaan muotoon geahčadehpet saa epäilemään, että koltansaamen muodossa jälkiosa - $e^{\prime} p e d$ muodostaa oman tahtinsa. Tekijää lienee harhauttanut se, että koltansaamessa toisen tahdin alkukonsonantti $d$ on supistunut pois. Tämä värä tahtijako on aiheuttanut pieniä virheitä muuallakin teoksessa. Esimerkiksi luvussa 5 (s. 118) käsitellään sananmuotoa luâšttõõttâd 'laskeutua' yksitahtisena ja sananmuotoa prosttjõõttâd 'pyytää anteeksi' kaksitahtisena, vaikka todellisuudessa molemmat ovat kaksitahtisia.

Kolmas luku käsittelee morfofonologiaa. Ensi tavussa vaihtelevien vokaalien jako "korkeaan" ja "matalaan" ryhmään on perusteltu, vaikka yhdessä vaihtelupareista $(a \sim \ddot{a})$ onkin kyse takaisemman ja etisemmän vokaalin vaihtelusta. Jaottelu selkiyttää koltansaamen vokaalivaihtelun teoreettista selitystä ja helpottaa pedagogisen kielioppimateriaalin luomista. Luvussa käsitellään myös konsonanttien astevaihtelua ja osoitetaan verbien taivutusmuotojen akustisten mittausten avulla, että koltansaamessa todella on kolme kestoastetta. Samaan tulokseen on päätynyt myös McRobbie-Utasi (1999), johon tekijä viittaakin.

Neljännessä luvussa esitellään koltansaamen sanaluokat: verbit, substantiivit, adjektiivit, pronominit, numeraalit, kvanttorit, adverbit, adpositiot sekä partikkelit, joiksi luetaan myös konjunktiot. Konjunktioiden esitys perustuu normitettuun yleiskieleen eikä ota huomioon sitä tosiseikkaa, että myös suomesta lainattuja konjunktiota (ja, vai, sitten, mutta, että jne.) esiintyy kielessä yleisesti. Ottaen huomioon kieliopin deskriptiivisen luonteen asiaan olisi voinut tässä kiinnittää huomiota. Ja- ja että-konjunktioiden esiintymiseen viitataan kuitenkin myöhemmin syntaksin yhteydessä (s. 292 ja 298-299).
Luvussa viisi käsitellään sananmuodostusoppia: deverbaalisia verbijohtimia, denominaalisia verbi- ja nominijohtimia sekä adjektiivi- ja adverbijohtimia. Lopuksi tarkastellaan yhdyssanojen muodostamista. Luku käsittää listan tärkeimmistä johdostyypeistä muodostusohjeineen ja on erinomainen lähtökohta koltansaamen johto-opin tutkimiselle.

Nominien taivutusta käsittelevä kuudes luku yhdessä verbintaivutusta käsittelevän kahdeksannen luvun ja morfofonologiaa käsittelevän kolmannen luvun kanssa muodostavat kirjan tärkeimmän panoksen koltansaamen kieliopin tutkimukselle. Taivutusta käsittelevien lukujen pohjana toimivat Suomikoltansaame-sanakirjan (Sammallahti \& Mosnikoff 1991) lopussa olevat lyhyet verbien ja nominien taivutustyyppien kuvaukset. Sanojen taivutusparadigmat on esitelty taulukoin, joista käy ilmi kunkin taivutusmuodon vokaalin korkeus, konsonanttikeskuksen pituusaste ja mahdollinen palatalisaatio. Paikoitellen esimerkkiparadigmoja voisi olla enemmänkin. Esimerkiksi nominien taivutusluokan 4 ainoa esimerkkisana on $e$-vartaloinen (luokka $4 \mathrm{C}$ ), eikä luokista 4A (â-vartaloiset) ja 4B ( $a$-vartaloiset) anneta yhtään taivutusesimerkkiä.

Koltansaamen nominien jako taivutusluokkiin on monimutkaista, eikä vakiintunutta luokkajakoa ole olemassa. Feistin ratkaisu on jakaa nominit kahteentoista taivutusluokkaan. Jako on suurimmaksi osaksi perusteltu, mutta joiltakin osin sitä olisi voinut muuttaa ja hiukan tiivistääkin. Esimerkiksi luokat 2A (suõl : suõlli), 3 (põõus : põhssâm) ja 4 (puu'ttes : pottaz) taipuvat samoin periaattein, ja niissä on samankaltainen astevaihtelu. Sama koskee luokkia 7 (hõ'ppi) ja 8 (pååttaǩ) sekä luokkia 5 (porrmõš) ja 10 (škooulne'ǩk ). Taivutusluokkajaon perustana olisi käytettävä ennemmin monikon kuin yksikön nominatiivia, sillä joissakin taivutustyypeissä yksikön nominatiivin muoto on ly- 
hentynyt, vaikka sanan taivutus on muuten pysynyt ennallaan.

Selvin virhe kuudennessa luvussa on adjektiivien komparatiivimuotojen luokitteleminen yhteen taivutusluokaksi 12. Taivutuksensa puolesta kaksitavuisten adjektiivien komparatiivit kuuluvat nähdäksemme Feistin taivutusluokkaan 5 (esim. moččääb 'kauniimpi' : yks. lokatiivi moččubust). Yksitavuisten adjektiivien komparatiivit taipuvat eri tavoin kuin kaksitavuisten adjektiivien, ja ne kuuluvat luokkaan 8 (esim. uu'ccab 'pienempi' : yks. lokatiivi uu'ccbest). Lisäksi yksitavuisten adjektiivien komparatiivien esimerkkiparadigma on virheellinen (uu'ccab : $\left.{ }^{*} u u^{\prime} c c o \tilde{b} a ̂ s t\right)$. Toinen huomauttamisen arvoinen virhe on se, että kaksitahtiset sanat tyyppiä kaammgaž 'pikku karhu' (yks. illatiivi kaamgi'žže) on virheellisesti pantu samaan taivutusluokkaan (luokka 9) jooggâžz'pikku joki' -tyyppisten yksitahtisten sanojen kanssa (yks. illatiivi jooggže). Kaammgaž-tyyppi vaatisi oman taivutusluokkansa. Lisäksi taivutusluokassa 9 on sivuutettu kokonaan sanat tyyppiä päärnaž 'poikanen (yks. illatiivi päärnže) ja kuâlaž 'kalanen' (yks. illatiivi kuâlže).

Käsittelemme seuraavaksi verbien taivutusta, vaikka Feistin teoksessa sitä käsitelläänkin vasta luvussa 8 ; välissä on nominilauseiden syntaksia käsittelevä luku 7. Verbien parissa jatketaan vielä luvussa 9, jossa käsitellään aikamuotoja, aspektia, moduksia ja negaatiota, joskin melko pintapuolisesti.

Koltansaamen verbien jaottelu taivutusluokkiin on yksinkertaisempaa kuin nominien. Verbien taivutusta käsittelevä kahdeksas luku esittää taivutusmallit ja taivutusluokkajaon järkevästi. Verbit jaetaan neljään taivutusluokkaan ja edelleen kolmeen alaluokkaan A-C infinitiivimuodon ensimmäisen tavun vokaalin korkeuden ja palatalisaation perusteella. Poikkeuksena on luokka 3, jossa alaluokkia on ainoastaan kaksi (palatalisoituneet ja palatalisoitumattomat). Luokkien tunnuspiirteet ovat sel- keät, ja luokat ovat verrattain selvärajaiset. Ainoa huomauttamisen arvoinen seikka on se, että esimerkkiparadigmoja saisi olla huomattavasti enemmän. Esimerkiksi taivutusluokasta 3 (jed-loppuiset verbit) ei ole annettu yhtään esimerkkiparadigmaa eikä edes imperatiivin yksikön toisen persoonan muotoa, joka on tämän ryhmän selvin määrittävä tekijä.

\section{Syntaksia}

Syntaksi on kirjassa jaettu kahteen osaan. Kuten edellä totesimme, nominilausekkeiden syntaksia käsitellään luvussa 7 heti nominien taivutuksen jälkeen, kun taas lausesyntaksia käsitellään luvussa 10. Ratkaisu on hiukan odottamaton ja rikkoo kieliopin selkeän rakenteen. Toki tässäkin järjestyksessä on oma järkensä, ja lienee mielipidekysymys, kumpaa pitää parempana vaihtoehtona.

Nominilausekkeiden yhteydessä käsitellään niiden rakennetta ja erilaisia määritteitä: adjektiiveja, partisiippeja, demonstratiiveja, numeraaleja, kvanttoreita ja relatiivilauseita. Numeraalien kollektiivijohdoksia ei kuitenkaan mainita lainkaan. Esimerkiksi sivuilla 190-191 käsitellään lausekkeita nellj oummu 'neljä ihmistä' ja lååi ooumžed 'kymmenen ihmistä' mutta sivuutetaan se, että ihmisryhmistä puhutaan usein myös kollektiivijohdoksilla neelljas 'nelikko' ja låå'jjes 'kymmenikkö. Sivulla 193 sananmuoto mäyggsest, joka on kollektiivijohdos kvanttorista mängg 'moni', on analysoitu virheellisesti vastaavan perussanan taivutusmuodoksi. Todellisuudessa kyseessä on sanan määngas 'monikko, monta ihmistä' taivutusmuoto.

Lauseiden syntaksia käsittelevä luku 10 alkaa katsauksella perussanajärjestykseen. Tämä osio on laajempi kuin Feistin väitöskirjassa, jossa hän esitti koltansaamen perussanajärjestyksen olevan SOV (Feist 2010: 278-283). Arvioitavaan teokseen aineistoa on otettu hieman enemmän 
kuin väitöskirjassa, ja tarkastelu on systemaattisempaa, minkä tuloksena perussanajärjestyksiä erotetaankin useita. Kun verbillä on vain yksi argumentti, ylivoimaisesti yleisimmät järjestykset ovat $\mathrm{SV}$ ja OV. Jos sekä subjekti että objekti ovat läsnä, SVO ja SOV ovat molemmat suhteellisen yleisiä, edellinen jopa hiukan yleisempi. Samansuuntaiseen tulokseen on päätynyt kandidaatintutkielmassaan myös Lehtinen (2016).

Luvun 10 loppuosassa käsitellään sijamuotojen käyttöä, predikaatiivisia konstruktioita, valenssia, passiivikonstruktiota, adverbeja ja adpositiolausekkeita sekä lauseyhdistelmiä. Esitys on varsin kattava, ja luku onkin sivumäärällisesti teoksen selvästi laajin lukuun ottamatta liitteeksi laskettavaa aineistolukua 11. Feist kuitenkin hyväksyy varsin kritiikittömästi sen, että verbin $f e^{\prime} r t t j e d$ 'täytyä' subjektin on oltava lokatiivissa. Tämä on ollut koltansaamen kirjakielen normi, mutta nauhoiteaineistosta ei löydy tukea sille väitteelle, että kyse olisi kielen luonnollisesta normista (Koltansaamen dokumentaatiohanke 2016: 25). Sen sijaan subjekti näyttäisi olevan useimmiten nominatiivissa, jolloin verbi taipuu tavalliseen tapaan. Feistin johtopäätös johtunee siitä, että suurin osa hänen tutkimusaineistostaan edustaa nimenomaan normitettua yleiskieltä.

\section{Lopuksi}

Vaikka Timothy Feistin kieliopissa on joitakin puutteita ja virheitä, se on laajuutensa ja perusteellisuutensa puolesta uraauurtava teos. Sen erityinen ansio on koltansaamen monimutkaisen taivutusjärjestelmän ja morfofonologisten vaihteluiden esittäminen ensimmäistä kertaa eksplisiittisesti ja järjestelmällisesti. Kiitämme tekijää suuresta ja tärkeästä työstä, joka on avannut koltansaamen tutkimuksen laajemmalle kansainväliselle yleisölle. Omasta kokemuksestamme tiedämme myös, että teos on korvaamaton apu koltansaamen opinnoissa.

$$
\begin{array}{r}
\text { MARKus JUUTINeN } \\
\text { etunimi.sukunimi@oulu.fi } \\
\text { MIIKA LeHTINEN } \\
\text { etunimi.sukunimi@student.oulu.fi }
\end{array}
$$

\section{Lähteet}

Feist, Timothy 2010: A grammar of Skolt Saami. Julkaisematon väitöskirja. Manchester: University of Manchester. https://www.escholar.manchester.ac.uk/ api/datastream?publicationPid=uk-acman-scw:123128\&datastreamId=FULLTEXT.PDF.

Koltansaamen dokumentaatiohanke $=$ Juutinen, Markus - Koponen, Eino - Koukkari, Tuomas - Miestamo, Matti 2016. http://www. giella.org/wp-content/uploads/2016/o1/ Koltansaamen-dokumentaatiohanke.pdf (27.4.2017).

Korhonen, Mikko - Mosnikoff, Jouni - Sammallahti, Pekka 1973: Koltansaamen opas. Castrenianumin toimitteita 4. Helsinki: SuomalaisUgrilainen Seura.

Lehtinen, Mirka 2016: Sää'mǩiõl vuâđđsää'nnjiârgg. Kandidaatintutkielma. Oulun yliopiston Giellagas-instituutti.

McRobiie-Utasi, Zita 1999: Quantity in the Skolt Saami (Lappish) language. An acoustic analysis. Uralic and Altaic Series 165. Bloomington, IN: Bloomington, Indiana University.

Mosnikoff, SAtu 1992: Maaddârää'jji mainnâz. Ohcejohka: Girjegiisá.

Moshnikoff, Satu - Moshnikoff, Jouni - Koponen, Eino 2009: Koltansaamen koulukielioppi. Sää'mǩiól ǩiôllvuä'ppes škoou'li vääras. Inari: Saamelaiskäräjät.

Sammallahti, Pekna 1998: The Saami languages. An introduction. Kárášjohka/ Karasjok: Davvi Girji. 


\section{Kielen matka puheesta kirjoitukseen - miten ja miksi}

Liisa Tiittula \& Pirkko Nuolijärvi (toim.): Puheesta tekstiksi. Puheen kirjallisen esittämisen alueita, keinoja ja rajoja. Suomalaisen Kirjallisuuden Seuran toimituksia 1424. Helsinki: Suomalaisen Kirjallisuuden Seura 2016. 286 s. ISBN 978-952-222-735-5.

Puhuttu ja kirjoitettu kieli ovat erilaisia. Tämä kahtiajako on monelle itsestäänselvyys, ja se heijastuu stereotyyppisiin käsityksiin puhekielen ja kirjakielen erillisistä, tarkkaan rajatuista käyttöyhteyksistä. Mutta kuten kieleen liittyvissä ilmiöissä yleensä, todellisuus on tässäkin monisyisempi. Vaikka puhuttu ja kirjoitettu kieli hyödyntävät erilaisia semioottisia kanavia, ne elävät usein myös rinnakkain ja limittäin: Tekstit kaikuvat puheissa, ja puhetta siirretään teksteiksi. Julkista puhetta kirjoitetaan ja korjaillaan yleensä useaan kertaan ennen sen esittämistä, kun taas keskustelupalstalle tai kännykkään lähetetty kirjoitus voi olla hyvinkin spontaanisti tuotettu ja viimeistelemätön. Tällaisissa puhutun ja kirjoitetun kielen leikkauspisteissä kielimuotojen tarkka kahtiajako hämärtyy ja esiin nousee semioottisen kanavan lisäksi monia muita tekijöitä, jotka vaikuttavat ihmisten tapoihin käyttää kieltä.

Liisa Tiittulan ja Pirkko Nuolijärven toimittamassa teoksessa tarkastellaan yhtä puhutun ja kirjoitetun kielen leikkauspistettä: niitä tilanteita, joissa puhetta siirretään kirjoitettuun muotoon. Puheesta tekstiksi: Puheen kirjallisen esittämisen alueita, keinoja ja rajoja esitte- lee teoreettisen pohjustuksen jälkeen seitsemän lähestymistapaa aiheeseen. Onnistuneesti tutkimusta ja omakohtaista ammattikokemusta eri tavoin yhdistelevät artikkelit esittelevät toimintatapoja, joilla eri alojen toimijat siirtävät spontaania puhetta tekstiksi. Kokoelmassa on valaisevia artikkeleita journalistien, tutkijoiden, kirjailijoiden ja kirjallisuuden kääntäjien, ohjelmatekstittäjien ja kirjoitustulkkien työstä sekä sitä ohjaavista tavoitteista. Teoksessa tarkastellaan myös eduskunnan pöytäkirjatoimiston toimintaa sekä automaattisia puheentunnistimia, joilla on sekä samanlaisia että erilaisia haasteita puheen käsittelemisessä kuin ihmisillä. Teos etenee teoriaan ja tutkimuksen tekemiseen painottuvista artikkeleista yksittäisistä aloista kertoviin teksteihin.

\section{Kuka siirtää puhetta tekstiksi, miten ja miksi}

Artikkeleissa esitellään paitsi eri aloilla eriasteisesti vakiintuneita käytäntöjä myös niitä yhteiskunnallisia tarkoitusperiä, joita varten puhetta esitetään tekstimuodossa. Johanna Ruusuvuori ja Pirjo Nikander tarkastelevat asiaa tutkimuksen teon kannalta artikkelissaan "Puheen litterointikäytännöistä eri tutkimustarkoituksiin". He esittelevät haastattelussa tai spontaanissa vuorovaikutuksessa tuotetun puheen litterointitapoja laadullisessa sisällönanalyysissa, diskurssianalyysissa ja keskustelunanalyysissa. Artikkeli on tiivis ja havainnollinen johdanto puhetta sisäl- 